\title{
LEAN, AGILE \& LEAGILE SUPPLY CHAIN: A COMPARATIVE STUDY
}

\begin{tabular}{|c|c|c|}
\hline Rajeev Kant & Vijay Pandey & L. N. Pattanaik \\
Dept. of Production Engineering & Dept. of Production Engineering & Dept. of Production Engineering \\
Birla Institute Technology & Birla Institute Technology & Birla Institute Technology \\
Mesra, Ranchi - 835215, India & Mesra, Ranchi - 835215, India & Mesra, Ranchi - 835215, \\
kant.rajeev@ gmail.com & vpandeybit@rediffmail.com & Indialnpattanaik@yahoo.com \\
\end{tabular}

\begin{abstract}
Lean and agile principles are two most buzzing words around the corporate in the past few decades. The industrial sectors throughout the world are upgrading to these principles to enhance their performance lowering their operating costs. Though, these principles have been proven to be efficient in handling supply chains, a more robust strategy is developed inheriting the salient features of both lean and agile principles. The synergy of the two principles, leagile, takes advantage of leanness by eliminating non-value added time and agility by additional reduction of value-added time via production technology breakthroughs. Though, all the three are directly focused on core competency, the suitability of each of them must be evaluated before implementation. The objective of this study is to perform a comparative analysis of the agile, lean and leagile supply chain which specifies the competitive features of the three strategies and their competency. In addition to this, different frameworks of leagile supply chain are presented suitable for different manufacturing industry. Key words-supply chain; lean; agile; le-agile; decoupling point
\end{abstract}

\section{INTRODUCTION}

With new innovation in production methodologies and communication technologies, market has witnessed a worldwide expansion and a dynamic situation due to increasing demand for customized product at minimum cost with least waiting time. In this prospect, lean and agile are two highly recognized concepts evolved in the pursuit of business excellence. Lean essentially is meant to do more with less - for example low inventory level and higher production efficiency, while Agile offers more for the same - for example giving more configuration to accommodate demand fluctuation and design change and delivery options for the same. Lean and agile, each provides distinct benefits. Both the principles have been proven to be efficient in handling supply chains, a more robust strategy is developed inheriting the salient features of both lean and agile principles. The synergy of the two principles, leagile, takes advantage of both leanness and agility. Leanness accentuates elimination of all forms of non value added activities to minimize the cost and time with exact quality a customer desires but lean might not be able to respond to stochastic fluctuations in customer demand while agile strategy enhance the responsiveness through virtual corporation among the manufacturers to tap profitable opportunities in such a stochastic market situation. Hence, many researchers have suggested not to select either a lean or agile strategy but to combine both strategies to reach faster to the end user [1].

A very conceptual definition to characterize a manufacturing system in regard to lean, agile and leagile has been given by Agarwal et al. [2] as follows:

$>$ Production is lean if it is done with minimal waste owing to unrequired and inadequate operations, or excessive buffering during production processes.

$>$ Production is agile if it changes operating maneuvor efficiently in response to uncertain and varying demands placed upon it.

$>$ Leagile manufacturing system should be viewed as an efficient coordination among the various production aspects of lean and agile production. It has a philosophical aspect which gives the organization a particular human resource dimension and a production dimension.

In the present work, the commonalities and difference between two competitive strategies, lean and agile is studied and the synergistic integration of the two, leagile is analyzed and different framework of leagile supply chain is presented.

The outline of the paper is as follows. Section 2 contains a literature review pertaining to lean, agile and leagile concepts. Section 3 presents a comparison study of lean, agile and leagile principles in context of supply chain. Finally the conclusion of the present study is briefed in section 4

\section{LITERATURE REVIEW}

\subsection{Lean Idioms}

Toyota production system (TPS) is considered as the pioneer of lean practice which was primarily evolved with a goal to minimize the cost by compressing the inventory levels at all points of operations or implementing Just-inTime (JIT) concept [3]. Although, JIT is understood as the forerunner of lean principle, the concepts and techniques 


\section{Asia Pacific Journals}

under the lean label were extended to five lean principles: customer value, value stream, flow, pull, and perfection [4]. These five principles are the driving force to identify the non value adding activities within the organization aiming to lower operating costs. In contrast of lean ideology, the non value adding activities are termed as waste (muda) and seven types of waste is defined as shown in Fig. 1 [5].

Since, the success of lean production is dependent upon contextual factors such as stable market, large infrastructural support and dominant technology, the concept of lean production is being shifted from manufacturing to outsourcing to cope up with the diversity of manufacturing.

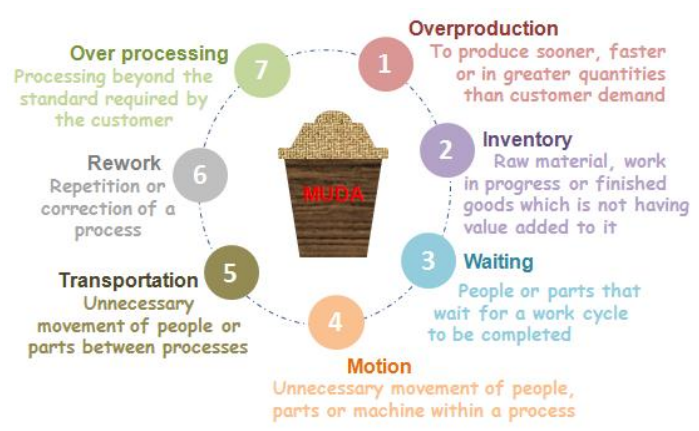

Figure 1. Waste in lean manufacturing

\subsection{Agility}

A number of definitions have been suggested for agility by various authors [6]. The most generic definition of agility can be "ability to sense environmental change and respond quickly by providing the appropriate capabilities".

In manufacturing concern, Gould [7] has defined agile manufacturing as, “... aims to meet the changing market requirements by suitable alliances based on corecompetencies, by organizing to manage change and uncertainty, and by leveraging people and information". Agile manufacturing refers specifically to the operational aspects of a manufacturing firm with a flexibility of producing goods and services by systematically developing compliance with other firms through information exchange and resource sharing to respond quickly and effectively to changing markets. Agile manufacturing does not emphasis on technical aspects as much as it is concerned with production management. It is a completely different way of doing business seeking overall improvements in pursuit of greater flexibility and real time demand. In this context, the concept of agile supply chain $[8,9]$ plays a key role to narrow the gap between production time and time to market. Fig. 2 depicts the most accepted model of agile supply chain developed by Harrison et al [10], constructed on four pillars; market sensitive, virtual collaboration, network, and process integration.

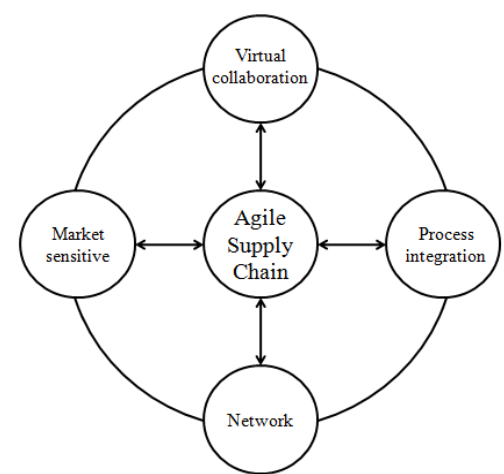

Figure 2. Four pillars of agile supply chain [10]

An agile strategy uses a wait-and-see approach to market demand until accurate demand is known. A suitable inventory of the subassembly of final products is hold with a lower-cost assembly process close to the point of demand in order to localize the product. It is the point where product differentiation happens, or in other words where products take their final shape, size and color. This point is referred to as decoupling point (DP).

\subsection{Leagility}

The concept of leagility in supply chain is introduced by Stevens [11]. This progression was promoted with a view that first there was a need to adopt the lean paradigm and now manufacturers should strive to become agile [12].

Leagile is the combination of the lean and agile paradigms within a total supply chain strategy separated by a decoupling point (figure 3 ) which is also termed as postponement strategy. Postponement could be explained as the segregation of products at the closest point to the end user [13] underlying the fact that if the goods are produced on demand rather than on forecast. It will all be sold.

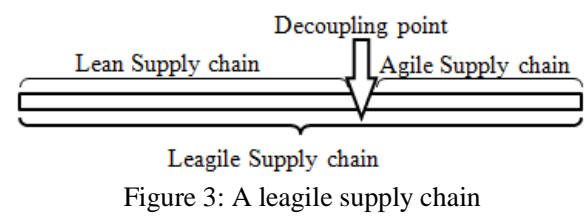

A lean supply chain focuses on promising the best customer value for a product ensuring the best quality. On the other hand, agile strategy ensures the minimum waiting time to deliver a product. Hence, many researchers have advocated that a lean focused supply chain model appears incomplete as agility became coveted. A number of case studies is available in literature from different industrial prospective indicates the growing interest of the leagile supply chain implementation $[12,14,15]$.

As stated above, a leagile supply chain essentially consists of lean and agile supply chain connected by means of a decoupling point. The significance of decoupling point 


\section{Asia Pacific Journals}

in a leagile supply chain is illustrated in Fig. 4 and it should be positioned best suited the need for responding to the customer demand downstream yet providing level scheduling upstream from the decoupling point. Fig. 5 shows a typical framework of leagile supply chain based on the placement of DP.

The choice of decoupling point is solely based on the nature of the product and demand, and the total lead-time, for example, in case of dairy industry, the decoupling point for milk may be placed at the distributor level where milk could be supplied directly from the producer and packed in various quantities as per demand.

\section{COMPARATIVE ANALYSIS}

\subsection{Comparison between lean and agile principles}

Both lean and agile concepts are directly focused on competitiveness, which is a constant concern in the global markets in which manufacturers compete. Both are the solutions to the upcoming challenges faced by traditional manufacturers, and both provide opportunities for smaller players to compete with larger and firmly established competitors. While discussing the commonalties and differences between lean and agile principles, the most generic perspective definition of leanness and agility is given by Naylor et al. [1] in a supply chain context as:

Leanness means developing a value stream to eliminate waste, including time, and to ensure a level schedule.

Agility means using market knowledge and a virtual corporation to exploit profitable opportunities in a volatile market place.

Level schedule means smooth flow of operations or process with minimum disruptions caused by sudden changes in demand. Hence, while ensuring a level scheduling, the operations must be kept away from volatility, protected from uncertainties and variations. In contrast, agile manufacturing includes collaboration of companies which are legally separated but similar operational aspects to encounter any uncertainties and variations in the volatile market.

Though, both lean and agile are coevally evolved, the merits of lean and agile supply chain strategies have been much debated among practitioners and academicians. Lean and agile, each provides distinct benefits. Lean manufacturing increases cash on hand by trimming expenses, while agile manufacturing increases revenue by being ready to serve a range of unexpected demands. Lean manufacturing allows companies the flexibility to reduce prices or use price promotions to attract new business, while agile manufacturing allows them to maximize the number of sales opportunities. Both concepts rely heavily on supply chain and logistic support, real time information systems and open communication between internal and external stakeholders.

The differences between lean and agile can be established by the way production style, inventory levels and resource management. Groover [16] compares both approaches and concludes that lean deals more with technical and operational issues while agile deals with organizational issues. Hence lean manufacturing applies to the factory while agile manufacturing applies to the enterprise. Table 1 insight a comparison of lean and agile manufacturing characteristics.

Table 1

Comparison of lean and agile manufacturing characteristics

\begin{tabular}{|l|l|}
\hline \multicolumn{1}{|c|}{ Lean manufacturing } & \multicolumn{1}{|c|}{ Agile manufacturing } \\
\hline $\begin{array}{l}\text { - is a response to competitive } \\
\text { pressures with limited } \\
\text { resources, }\end{array}$ & $\begin{array}{l}\text { - is a response to complexity } \\
\text { brought by unforeseen } \\
\text { change, }\end{array}$ \\
\hline $\begin{array}{l}\text { is bottom-up driven, } \\
\text { incrementally transforming the } \\
\text { mass-production model, }\end{array}$ & $\begin{array}{l}\text { is top down driven } \\
\text { responding to distributed } \\
\text { production model, }\end{array}$ \\
\hline $\begin{array}{l}\text { - is a collection of operational } \\
\text { tactics focused on productive } \\
\text { use of resources, }\end{array}$ & $\begin{array}{l}- \text { is an overall strategy } \\
\text { focused on succeeding in an } \\
\text { unpredictable environment, }\end{array}$ \\
\hline $\begin{array}{l}\text { - brings flexibility through } \\
\text { multiuse work modules, }\end{array}$ & $\begin{array}{l}- \text { brings flexibility through } \\
\text { reconfigurable work modules } \\
\text { - }\end{array}$ \\
\hline - is process focused. & - is procurement focused. \\
\hline
\end{tabular}

Lean and agile both seem to be entirely different framework, effective and real time communication technologies are the foundation of lean and agile initiatives. Both the manufacturing models require accurate and timely information about the inventory, labor and production. This commonality forms the base of bridging the two paradigms. 


\section{Asia Pacific Journals}

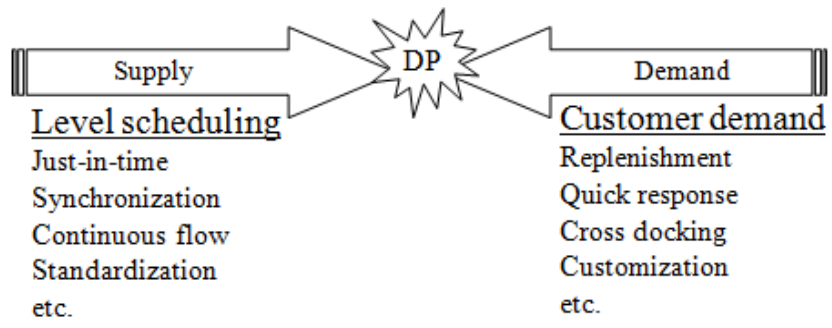

Fig. 4. Function of decoupling point in a leagile supply chain

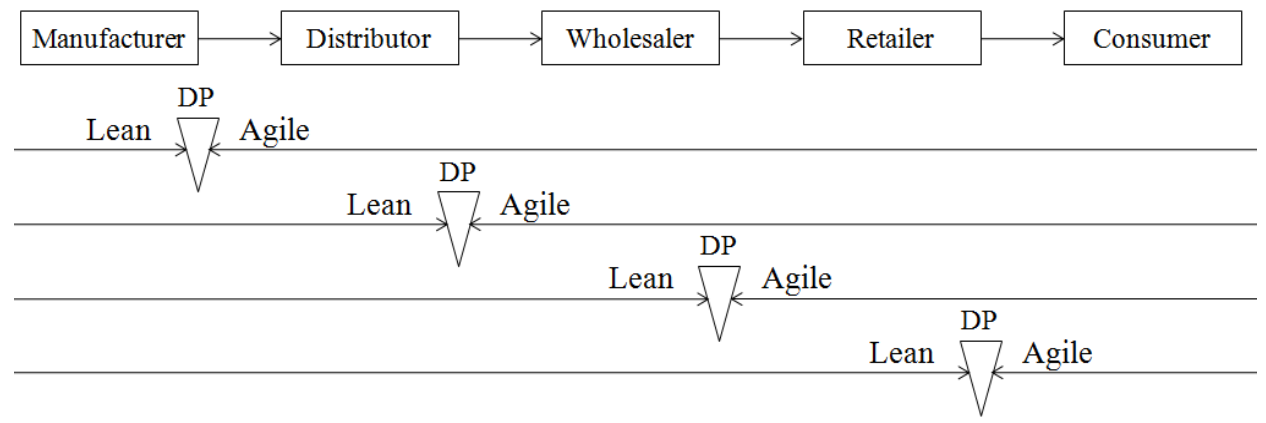

Fig. 5. Different frameworks of leagile supply chain

\subsection{Comparison between lean, agility and leagile supply chain}

The previous section presents a comparative analysis of leanness and agility in sight of their competitive edges. But, still the question of "either, or, or both" is a matter of contradiction among the decision makers. Findings from case studies from fashion and textile industry and simulation results performed by Hilletofth and Hilmola [17] support the lean approach more adequate than leagile approach in long term. Though, many researchers urge that neither of them supersedes each other rather they complement each other and both should be combined to gain a better competitive advantage. Al Samman [18] has suggested that neither of lean, agile and leagile are exclusive rather they are complementary. and yet it is likely that each would work better than others in certain contexts. Hence, the choice of these strategies should be based upon a careful analysis.

In this regard, authors have summarized the major characteristics of the lean, agile and leagile supply chains from different perspectives as can be seen in table 2 .

Table 2

Comparison between Lean, Agile and Leagile Supply Chain

\begin{tabular}{|l|c|c|c|}
\hline \multicolumn{1}{|c|}{ Perspectives } & Lean Supply Chain & Agile Supply Chain & Leagile Supply Chain \\
\hline Market type & Concentrated & Fragmented & Versatile \\
\hline Market demand & Predictable & Volatile & Volatile and unpredictable \\
\hline Sensitivity to demand fluctuation & Low & High & Moderate \\
\hline Product variety & Low & High & Medium \\
\hline Sensitivity to change in product design & Low & High & Moderate \\
\hline Cost of small quantities relative to large quantities & High & Same & Same \\
\hline Product life cycle & Long & Short & Short \\
\hline Product characteristics & Standard & Customized & Modular \\
\hline Product type & Functional & Trendy & As per customer demand \\
\hline Cost endorsement & Location based & Market based & Based on customer preference \\
\hline Time compression & Cycle time & Delivery time & Total lead time \\
\hline Inventory level & Low & High & Medium \\
\hline Focus on muda elimination & Essential & Desirable & Arbitrary \\
\hline
\end{tabular}




\section{Asia Pacific Journals}

\begin{tabular}{|l|c|c|c|}
\hline Robustness & Arbitrary & Essential & Desirable \\
\hline Rapid reconfiguration & Desirable & Essential & Essential \\
\hline Product marketing & Reactive & Proactive & Responsive \\
\hline Customer approach & Quick & Quicker & Quicker \\
\hline
\end{tabular}

\section{CONCLUSION}

In the present study, a comparative analysis has been performed highlighting various aspects of lean, agile and leagile strategy in supply chain context. This work is intended to serve three purposes: i) to provide meaningful descriptions of three much debated lean, agile and leagile supply chain strategies, ii) to enlighten the commonalities and differences between lean and agile manufacturing, and iii) to describe major characteristics of the lean, agile and leagile supply chains.

In today's market, demand for new products emerges at an accelerated pace, it has become more important to bring in new products at a matching pace. The responsiveness and delivery have become the primary concern of manufacturing industry due to fast changing consumer preferences. On the other hand, companies are focusing on increasing their market share by expanding their market irrespective of territorial constraint. The present study can be used as a guideline to help selecting an appropriate strategy according to the business environment of a manufacturer.

\section{REFERENCES}

[1] Naylor, J.B., Naim, M.M., and Berry, D., "Leagility: integrating the lean and agile manufacturing paradigms in the total supply chain", International Journal of Production Economics, 1999, 62, pp. 107-18.

[2] Agarwal, A., Shankar, R., and Tiwari, M.K., "Modeling the metrics of lean, agile and leagile supply chain: An ANPbased approach", European Journal of Operational Research, 2006, 173, pp. 211-225.

[3] Taiichi O., Toyota Production System: Beyond Large-Scale Production. MIT: Productivity Press, 1988.

[4] Womack, J.P. and Jones, D.T., Lean Thinking. New York: Simon \& Schuster, 1996.

[5] Womack, J.P., Jones, D.T., and Roos, D., The machine that changed the world. New York: Rawson Associates, 1990.

[6] Agarwal, A., Shankar, R., and Tiwari, M.K., "Modeling agility of supply chain", Industrial Marketing Management, 2007, 36, pp. 443-457.

[7] Gould, P., "What is agility", Manufacturing Engineer, 1997. 76(1), pp. 28-31.

[8] Christopher, M., "The agile supply chain: Competing in volatile markets", Industrial Marketing Management, 2000, 29, pp 37-44.

[9] Christopher, M., Lowson, R., and Peck, H., "Creating agile supply chains in the fashion industry", International Journal of Retail \& Distribution Management, 2004, 32(8), pp. 367 376.

[10] Harrison, A., Christopher, M., and van Hoek, R. "Creating the agile supply chain", Institute of Logistics \& Transport, Corby, UK, 1999.

[11] Stevens, J., "Integrating the supply chain", International Journal of Physical Distribution and Materials Management, 1989, 19(8), pp. 3-8.

[12] Mason-Jones, R., Naylorz, B., and Towillz, D.R., "Lean agile or leagile? Matching your supply chain to the marketplace", International Journal of Production Research, 2000, 38(17), pp. 4061-4070.

[13] Ernst, R. and Kamrad, B., "Evaluation of supply chain structures through modularized and postponement", European Journal of Operation Research, 2000, 124, pp. 495-510.

[14] Naim, M., Naylor, J., and Barlow, J., "Developing lean and agile supply chains in the UK house building industry", Proceedings of IGLC-7, University of California, Berkeley, CA, USA, 26-28 July, 1999, pp.159-170.

[15] Margaret Bruce, Lucy Daly, Neil Towers. (2004). "Lean or agile: A solution for supply chain management in the textiles and clothing industry?", International Journal of Operations \& Production Management, 24(2), pp.151-170.

[16] Groover, M.P., Automation, Production Systems, Computer-integrated Manufacturing. Prentice Hall, 2008.

[17] Hilletofth, P. and Hilmola, O.P., "Supply chain management in fashion and textile industry", International Journal of Services Sciences, 2008, 1(2), pp. 127-147.

[18] Al Samman, T.A.S., "Modelling lean, agile, leagile manufacturing strategies: A fuzzy analytical hierarchy process approach for readymade ware (clothing) industry in Mosul, Iraq", International Journal of Advances in Engineering \& Technology, 2014, 7(3), pp. 1091-1108. 